\title{
EGG IMPLANTATION AND DECIDUOMA INDUCTION IN CYCLIC MICE AFTER TREATMENT WITH PROGESTAGENS AND OESTRADIOL
}

\author{
P. S. GRANT AND ANNE McLAREN \\ Institute of Animal Genetics, \\ West Mains Road, Edinburgh, EH9 $37 \mathcal{N}$
}

(Received 27th Fuly 1972)

\begin{abstract}
Summary. Mice were treated with one of the potent progestagens, medroxyprogesterone acetate (MAP) or melengestrol acetate (MGA), at different stages of the oestrous cycle. They were tested for deciduoma induction, or for egg implantation, by oestradiol treatment combined with either injection of air into the uterine lumen or transfer of blastocysts to the uterus. The two important variables for both deciduoma induction and egg implantation were the MAP-oestradiol interval and the stage of the oestrous cycle during which the progestagens were injected. Maximal uterine sensitivity was obtained after the injection of MAP during oestrus with a 4-day MAP-oestradiol interval. Under these conditions, $34 \%$ of the transferred blastocysts developed to fullterm viable fetuses. The injection of MAP or MGA did not usually induce pseudopregnancy as judged by the activation of cyclic CL; hence, the pregnancies were maintained by the activity of the injected progestagens.
\end{abstract}

\section{INTRODUCTION}

The mouse uterus is receptive to transferred eggs during the $3 \mathrm{rd}$ and 4 th days of pregnancy or pseudopregnancy (McLaren \& Michie, 1956), and is maximally sensitive to decidualizing stimuli on the 4th day (Finn, 1965). The receptive period is prolonged by lactation, and by ovariectomy in early pregnancy, followed by progesterone treatment; implantation can then be induced at any time by the injection of oestrogen (Whitten, 1955; Yoshinaga \& Adams, 1966). The present work was undertaken to determine if progestagen treatment of cyclic mice would similarly render their uteri receptive so that subsequent sensitization could be controlled by exogenous oestrogen. If so, mice prepared in this way could be used as recipients for egg transfers, obviating the need to induce pseudopregnancy by mating with vasectomized males.

\section{MATERIALS AND METHODS}

Sensitization was tested by the injection of $0.02 \mathrm{ml}$ air into the left uterine horn about $7 \mathrm{hr}$ after the injection of oestrogen, or by the transfer of morulae or 
blastocysts (usually six per mouse) from donor mice $3 \frac{1}{2}$ days post coitum $24 \mathrm{hr}$ before oestrogen injection of recipient mice. Deciduomata were assessed 3 to 4 days after the injection of air: mice with swellings in the left horn were considered to have responded, and the difference in weight between the two horns was taken as an estimate of the size of the response. Implantation of transferred eggs was assessed at laparotomy 6 days after transfer, and fetal survival was examined at autopsy 10 days later (i.e. at term). At autopsy, ovaries were checked for CL and weighed, and some were examined histologically.

Hormones were injected subcutaneously: $6 \alpha$-methyl-1 $7 \alpha$-acetoxyprogesterone (MAP, medroxyprogesterone acetate; Depoprovera, Upjohn) in $0.05 \mathrm{ml}$ vehicle; $1 \mathrm{mg} 17 \alpha$-acetoxy-6-methyl-16-methylene pregna-4,6-diene-3,20-dione (melengestrol acetate, MGA; Upjohn) in $0.1 \mathrm{ml}$ of $2 \%$ methyl cellulose; and oestradiol-17 $\beta$ (Koch-Light) in $0.1 \mathrm{ml}$ arachis oil. Since the proportion of transferred eggs represented by swellings was similar with $2.5,5.0$ and $7.5 \mathrm{mg}$ MAP, a standard dose of $2.5 \mathrm{mg}$ was used. For oestradiol, $6 \mathrm{ng}$ and $15 \mathrm{ng}$ gave a similar response, but $37.5 \mathrm{ng}$ gave a lower response than either $(P<0.01): 15 \mathrm{ng}$ oestradiol was therefore adopted as a standard dose.

Virgin, cyclic 6- to 9-week-old female mice of the $Q$ strain were used. Cycles were followed by daily vaginal smears or by observation of externally visible vaginal changes: the results of the two methods agreed. The four successive cycle stages recognized were pro-oestrus, oestrus, metoestrus-1 (M-1) and metoestrus-2 (M-2) which included dioestrus. Artificial lighting (16 $\frac{1}{2} \mathrm{hr}$ light/ $7 \frac{1}{2} \mathrm{hr}$ dark centred on 01.30 hours) was used for all experiments. Data showing discontinuous variation were analysed by $\chi^{2}$ tests or by Fisher's exact method. Data showing continuous variation were analysed by Student's $t$ test and by correlation and regression techniques, after appropriate transformation of percentages. Differences between replicate experiments were not significant: pooled data are therefore presented in the tables.

\section{RESULTS}

The results of deciduoma induction after MAP injection at different stages of the oestrous cycle, and oestradiol 4 days later, are given in Table 1. The proportion of mice with deciduomata was heterogeneous $(P<0.05)$, and was highest after injection of MAP during oestrus. The quantitative response was consistently (although non-significantly) highest after the injection of MAP during oestrus and lowest after injection of MAP during M-2 and dioestrus. When an additional large dose of oestradiol $(0.5 \mu \mathrm{g})$ was injected simultaneously with the MAP, the quantitative response showed significant variation with cycle stage, being lowest after injections during pro-oestrus.

When MAP was given during oestrus and oestradiol and air were injected 2 to 5 days later, the proportion of mice responding depended on the interval $(P<0.05)$ but the size of the response did not vary significantly (Table 2$)$. A 4-day interval gave the highest proportion of mice responding and also the largest deciduomata. The probability of deciduoma induction was not related to the presence of active (i.e. red) CL at the time of air injection or at autopsy, nor was any correlation found between the decidual response and ovarian 
Table 1. The effect of stage of oestrus on the induction of deciduomata in mice by air injected into the oestrogensensitized uterus, 4 days after MAP injection with or without oestrogen priming

\begin{tabular}{|c|c|c|c|c|}
\hline \multirow{2}{*}{$\begin{array}{c}M A P \text { injection } \\
\text { during }\end{array}$} & \multirow{2}{*}{$\begin{array}{c}\text { 'Priming' } \\
\text { oestrogen } \\
(\mu \mathrm{g})\end{array}$} & \multicolumn{2}{|c|}{ No. of mice } & \multirow{2}{*}{$\begin{array}{l}\text { Mean } \dagger \text { response } \\
\text { in } m g \pm S . E .\end{array}$} \\
\hline & & Total & $\begin{array}{c}\text { With } \\
\text { deciduomata }\end{array}$ & \\
\hline $\begin{array}{l}\text { Oestrus } \\
\text { Metoestrus } 1 \\
\text { Metoestrus } 2^{*} \\
\text { Pro-oestrus }\end{array}$ & $\begin{array}{l}- \\
\overline{-} \\
-\end{array}$ & $\begin{array}{l}16 \\
10 \\
13 \\
10\end{array}$ & $\begin{array}{r}12 \\
3 \\
2 \\
4\end{array}$ & $\begin{array}{l}94 \cdot 7 \pm 24 \cdot 4 \\
60 \cdot 6 \pm 58 \cdot 1 \\
10 \cdot 5 \pm 10 \cdot 5 \\
36 \cdot 8 \pm 23 \cdot 3\end{array}$ \\
\hline $\begin{array}{l}\text { Oestrus } \\
\text { Metoestrus } 1 \\
\text { Metoestrus 2* } \\
\text { Pro-oestrus }\end{array}$ & $\begin{array}{l}0.5 \\
0 \cdot 5 \\
0 \cdot 5 \\
0.5\end{array}$ & $\begin{array}{l}4 \\
4 \\
8 \\
4\end{array}$ & $\begin{array}{l}3 \\
4 \\
6 \\
2\end{array}$ & $\begin{array}{r}48 \cdot 3 \pm 12 \cdot 5 \\
80 \cdot 5 \pm 40 \cdot 8 \\
44 \cdot 0 \pm 15 \cdot 3 \\
4 \cdot 0 \pm 2 \cdot 0\end{array}$ \\
\hline
\end{tabular}

* Includes mice in dioestrus.

$\uparrow$ Measured 3 days after the injection of air.

weight. Removal of both ovaries at the time of injection of MAP increased the proportion of mice with deciduomata $(P<0.05)$ and reduced the size of the response, though not significantly (Table 2 ).

The stage of the oestrous cycle and the MAP-oestradiol interval affected not only deciduoma induction but also the fate of the transferred eggs. With a 4-day interval, the proportion of eggs represented by swellings (Table 3) was higher after MAP had been injected during oestrus than after its injection during M-1 $(P<0.001)$ and M-2 $(P<0.001)$. No live fetuses were recovered following the injection of MAP during either day of metoestrus and a higher proportion of transferred eggs developed to full-term viable fetuses after MAP injected during oestrus than after its injection during pro-oestrus $(P<0.05)$. A higher proportion of transferred eggs represented by swellings and live fetuses followed the injection of MGA during oestrus than during metoestrus. The simultaneous injection of a large dose of oestradiol $(0.5 \mu \mathrm{g})$ increased the response to MAP during metoestrus (Table 3 ), as judged both by the proportion of mice with

Table 2. The effect of MAP-oestradiol interval on the induction of deciduomata in intact or ovariectomized mice

\begin{tabular}{|c|c|c|c|c|}
\hline \multirow{2}{*}{ Status } & \multirow{2}{*}{$\begin{array}{c}M A P \text {-oestradiol } \\
\text { interval }\end{array}$} & \multicolumn{2}{|r|}{ No. of mice } & \multirow{2}{*}{$\begin{array}{l}\text { Mean response } \\
\text { in } \mathrm{mg} \pm S . E \text {. }\end{array}$} \\
\hline & & Total & With deciduomata & \\
\hline Intact & $\begin{array}{l}2 \\
3 \\
4 \\
5\end{array}$ & $\begin{array}{l}4 \\
21 \\
28 \\
19\end{array}$ & $\begin{array}{r}1 \\
15 \\
21 \\
7\end{array}$ & $\begin{array}{l}69 \cdot 0 \\
58 \cdot 3 \pm 20 \cdot 7 \\
84 \cdot 3 \pm 17 \cdot 4 \\
77 \cdot 9 \pm 30 \cdot 4\end{array}$ \\
\hline Ovariectomized & $\begin{array}{l}3 \\
4 \\
5\end{array}$ & $\begin{array}{l}5 \\
9 \\
6\end{array}$ & $\begin{array}{l}4 \\
9 \\
6\end{array}$ & $\begin{array}{l}15 \cdot 7 \pm 7 \cdot 4 \\
43 \cdot 0 \pm 17 \cdot 3 \\
32 \cdot 7 \pm 18 \cdot 2\end{array}$ \\
\hline
\end{tabular}

MAP was injected during oestrus. 
Table 3. Implantation and survival after transfer to recipient mice treated 4 days previously with MAP or MGA at different stages of the oestrous cycle, with and without 'priming' oestrogen

\begin{tabular}{l|r|c|c|c|c}
\hline & \multicolumn{2}{|c|}{$\begin{array}{c}\text { No. of mice } \\
\text { Treatment and }\end{array}$} & $\begin{array}{c}\text { No. of eggs } \\
\text { stage of cycle }\end{array}$ & $\begin{array}{c}\text { \% of eggs } \\
\text { represented } \\
\text { as swellings }\end{array}$ & $\begin{array}{c}\text { No. of viable } \\
\text { fetuses as \% of } \\
\text { transferred eggs }\end{array}$ \\
\cline { 2 - 4 } & Total & $\begin{array}{c}\text { With } \\
\text { swellings }\end{array}$ & & & \\
\hline MAP & & & & & \\
Oestrus & 13 & 12 & 76 & $64 \cdot 5$ & $32 \cdot 9$ \\
Metoestrus 1 & 3 & 1 & 18 & $16 \cdot 7$ & 0 \\
Metoestrus 2 & 12 & 4 & 65 & $7 \cdot 7$ & 0 \\
Pro-oestrus & 5 & 4 & 30 & $56 \cdot 7$ & $16 \cdot 7$ \\
MGA & 5 & 5 & 31 & $77 \cdot 5$ & $32 \cdot 2$ \\
Oestrus & 5 & 3 & 33 & $15 \cdot 1$ & 0 \\
Metoestrus & & & & & \\
MAP+'priming' & & & & & \\
oestrogen & 6 & 4 & 24 & 45.9 & - \\
Metoestrus 1 & 6 & 5 & 32 & $34 \cdot 4$ & - \\
Metoestrus 2 & 6 & & & & \\
\hline
\end{tabular}

swellings after egg transfer $(P<0.05$ for M-2) and by the proportion of eggs represented by swellings $(P<0.05$ for $\mathrm{M}-1 ; P<0.001$ for $\mathrm{M}-2)$.

When MAP was injected during oestrus (Table 4), the proportion of eggs represented by swellings was higher when the MAP-oestradiol interval was 4 days than when it was 3 days $(P<0.01)$ or 5 days $(P<0.001)$. The lowest proportion of eggs represented by swellings was observed after transfer with a 17-day MAP-oestradiol interval. The proportion of eggs developing to viable fetuses was not significantly different for the 3- and 4-day intervals, but was strikingly lower for the 5-day interval.

Table 4. The effect of MAP-oestradiol interval on implantation and survival of embryos after transfer to cyclic recipient mice treated with MAP during oestrus

\begin{tabular}{c|c|c|c|c}
\hline $\begin{array}{c}\text { MAP-oestradiol } \\
\text { interval (days) }\end{array}$ & No. of mice & $\begin{array}{c}\text { No. of eggs } \\
\text { transferred }\end{array}$ & $\begin{array}{c}\% \text { of eggs } \\
\text { represented } \\
\text { as swellings }\end{array}$ & $\begin{array}{c}\text { No. of viable } \\
\text { fetuses as \% of } \\
\text { transferred eggs }\end{array}$ \\
\hline 3 & 5 & 26 & $57 \cdot 7$ & 26.9 \\
4 & 13 & 75 & $82 \cdot 7$ & $34 \cdot 7$ \\
5 & 8 & 46 & $34 \cdot 8$ & $2 \cdot 2$ \\
17 & 5 & 29 & $17 \cdot 2$ & - \\
\hline
\end{tabular}

With MAP at oestrus and a 4-day MAP-oestradiol interval, neither the proportion of eggs represented by swellings nor the proportion of swellings that developed into live full-term fetuses proved to be correlated with ovarian weight. Only four mice had active CL at autopsy: all had viable fetuses and their uteri resembled those of normal full-term pregnant mice. Mice without active CL often had hypertonic uteri with the fetuses crowded together and compressed. Ovarian weight at autopsy depended neither on the initial stage of the cycle nor on the MAP-oestradiol interval. 
Histological examination confirmed that mice treated with MAP or MGA did not ovulate and seldom had CL 19 to 22 days after treatment. Cyclic CL were usually small 7 to 8 days after MAP treatment. A few mice had large healthy CL scored as 'active' with a dissecting microscope and confirmed histologically. Most of the large follicles were degenerating and all ovaries contained abundant interstitial tissue. Mice with live fetuses at autopsy showed development of mammary tissue (confirmed histologically) but this was largely absent from mice with embryos that died early in pregnancy.

\section{DISCUSSION}

These results show that, in mice, the injection of MAP (or MGA) during oestrus seldom activated the cyclic CL to induce pseudopregnancy. In rats, progestagens, prolactin, androgens and a variety of chemicals can induce pseudopregnancy if injected during or beginning at oestrus (see review by Everett, 1966). The proportion of eggs that implant following transfer to pseudopregnant rats varies with the hormonal method of induction used (Banik \& Ketchel, 1965; Mantalenakis \& Ketchel, 1966). The latter workers found that injection of MAP at oestrus and metoestrus was as effective a method for the induction of pseudopregnancy as mating with vasectomized males, in terms of the proportion of transferred eggs developing to fetuses. In the present study, the most suitable scheme both for the induction of deciduomata and for fetal development after egg transfer was the injection of MAP (or MGA) during oestrus followed by the injection of oestradiol 4 days later. Pro-oestrus was the only other cycle stage when an injection of MAP allowed the development of some viable full-term fetuses.

The importance of injecting the progestagens during oestrus for subsequent uterine sensitivity suggests that the time of their action relative to the release of pro-oestrous oestrogen is important. This is confirmed by the improvement in subsequent uterine sensitivity after the simultaneous treatment of mice at metoestrus with MAP and $0.5 \mu \mathrm{g}$ oestradiol. The endogenous release of oestrogen during pro-oestrus 'primes' the uterus for subsequent progesterone action during normal pregnancy and pseudopregnancy. Weichert (1928) first demonstrated that deciduomata could be induced in ovariectomized rats given 'corpus luteum extract' after oestrogen priming. Priming with oestrogen has since been demonstrated to be necessary for maximal deciduoma formation in ovariectomized rats (see review by De Feo, 1967) and mice (Finn, 1966) treated with progesterone. With regard to the implantation of transferred eggs, the situation is less clear, since Humphrey (1969) found that oestrogen priming in ovariectomized mice did not lead to any significant increase in the number of eggs implanting.

In the present experiments, the 4-day MAP-oestradiol interval between the progestagen injection and the sensitizing dose of oestradiol gave the best results for deciduoma induction (Table 2) and egg transfer (Table 4), with the 3-day interval almost as good. If the oestrous stage, when MAP is injected is regarded as equivalent to the 1st day of pregnancy, the 3-day interval gives the closest approximation to the timing of events in normal pregnancy. The effectiveness 
of the 4-day interval suggests that receptivity is extended by about 1 day relative to normal pregnancy. A similar extension has been observed with eggimplantation and deciduoma induction in ovariectomized non-pregnant mice (Finn, 1966; Humphrey, 1969).

It is probable that the treatment of intact cyclic mice with progestagens did not abolish endogenous oestrogen release. Survival of fetuses to term was rare in mice ovariectomized on the 6th to 8th day of pregnancy and treated with MAP unless daily oestradiol was also given (Grant, 1972) yet, in the present work, full fetal development occurred in mice with no CL at autopsy. Further, MAP injected on the 1st day of pregnancy delayed implantation in rats (Barnes \& Meyer, 1964; Nutting \& Sollman, 1967) but not in mice (Grant, 1972), suggesting that release of the oestrogen required for implantation was not inhibited in mice.

Fetal survival was lower when MAP was given during pro-oestrus and after the 5-day MAP-oestradiol interval than when MAP (or MGA) was given at oestrus with the 4-day interval (see Tables 3 and 4). A comparison of the quantitative deciduomata and the proportion of eggs represented by live fetuses indicates that embryonic survival was highest when uteri were most sensitive to injected air. This suggests that the high mortality under other conditions was due to asynchrony between the time of egg transfer and the hormonal state of the uterus, which may have been influenced by the continued release of oestrogen. Although most of the difference between the number of uterine swellings at laparotomy and the number of fetuses at autopsy was due to embryonic death (verifiable at autopsy), some of the swellings did not contain embryos and may have represented traumatic deciduomata.

The disadvantage of the hormonal method from the point of view of providing egg-transfer recipients is that it requires events to be precisely timed in relation to the oestrous cycle in order to induce maximum uterine sensitivity. This requirement probably reflects both the influence of oestrogen at pro-oestrus, in setting the time limits for subsequent uterine sensitivity, and the release of endogenous oestrogen which could interfere with sensitivity induced by exogenous oestrogen. Treatment with MAP seems less effective in suppressing gonadotrophin release in mice than in rats and this may be one reason why MAP did not induce pseudopregnancy in mice.

\section{ACKNOWLEDGMENT}

We are grateful to the Ford Foundation for financial support.

\section{REFERENCES}

BANIK, U. K. \& KETCheL, M. M. (1965) Hormonal induction of pseudopregnancy in rats. F. Reprod. Fert. 10, 85.

BarNes, L. E. \& MeYer, R. K. (1964) Delayed implantation in intact rats treated with medroxyprogesterone acetate. 7. Reprod. Fert. 7, 139.

De Feo, V. J. (1967) Decidualization. In: Cellular Biology of the Uterus, chap. 8. Ed. R. M. Wynn. Meredith, Amsterdam.

Everetr, J. W. (1966) The control of the secretion of prolactin. In: The Pituitary Gland, Vol. 2, Anterior Pituitary, chap. 5. Eds. G. W. Harris and B. T. Donovan. Butterworths, London. 
FinN, G. A. (1965) Oestrogen and the decidual cell reaction of implantation in mice. F. Endocr. 32, 223.

Fins, C. A. (1966) Endocrine control of endometrial sensitivity during the induction of the decidual cell reaction in the mouse. F. Endocr. 36, 239.

Grant, P. S. (1972) Studies on the hormonal basis of egg implantation in mice. Ph.D. thesis, Edinburgh University.

HUMphrey, K. W. (1969) Induction of implantation of blastocysts transferred to ovariectomized mice. J. Endocr. 44, 299.

McLaren, A. \& Michie, D. (1956) Studies on the transfer of fertilized mouse eggs to uterine fostermothers. I. Factors affecting the implantation and survival of native and transferred eggs. F. exp. Biol. 33, 394.

Mantalenakis, S. J. \& Ketchel, M. M. (1966) Pseudopregnant recipients for blastocyst transfer in rats. Int. F. Fert. 11, 318.

Nutting, E. F. \& Sollman, P. B. (1967) Delay of implantation in intact rats treated with progestins. Acta endocr., Copenh. 54, 8.

Weichert, C. K. (1928) Production of placentomata in normal and ovariectomised guinea pigs and albino rats. Proc. Soc. exp. Biol. Med. 25, 490.

Whitten, W. K. (1955) Endocrine studies on delayed implantation in lactating mice. F. Endocr. 13, 1.

Yoshinaga, K. \& Adams, C. E. (1966) Delayed implantation in the spayed, progesterone treated adult mouse. F. Reprod. Fert. 12, 593. 